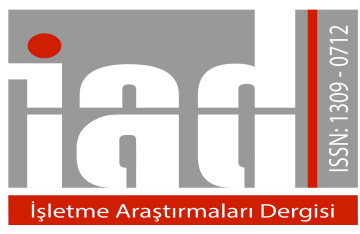

Journal Of

Business Research

Turk

www.isarder.org

\title{
The Effects of Tourism on Certain Variables: Exploring the Perceptions of Entrepreneurs*
}

\author{
Oktay EMíR \\ Anadolu University \\ Faculty of Business Administration \\ Eskisehir, Turkey \\ orcid.org/0000-0002-7972-1980 \\ oktayemir@anadolu.edu.tr
}

\begin{abstract}
The objective of this study is to determine how entrepreneurs perceive the economic, social and physical impacts of tourism. The study was conducted in the city of Afyonkarahisar, Turkey, which is rich in thermal tourism resources and investments. A survey was used as the data collection method, and the questionnaire was applied to 472 entrepreneurs. A simple random sampling method was used to identify the sample. Independent sampling t-tests, ANOVA tests and structural equation modelling were used to analyse the data obtained. The study found that the entrepreneurs expressed both positive (such as increases in the public's consciousness, job creation and the preservation of tourism values) and negative (such as the disappearance of moral and religious values, the transfer of tourism revenue and the disappearance of tourism resources) opinions on the impacts of tourism. Additionally, some statistically significant differences $(\mathrm{p}<.05)$ were found based on the participants' demographic characteristics regarding their opinions about the social, economic and physical impacts of tourism activities.
\end{abstract}

Keywords: Tourism, Perception, Entrepreneurship, Entrepreneurs, Structural Equation Modelling

\section{Introduction}

Tourism has various important economic, social and physical implications for societies. Tourism is viewed today as one of the most important factors in the growth and development of both developed and developing countries. Tourism can provide important contributions to improving the employment and income levels of society by reducing external debt, improving the balance of payments and especially improving the welfare of individuals (Seetanah, 2011, pp. 292-293; Nunkoo, 2015, pp. 625-626).

\footnotetext{
- This is an extended and unabridged version of the paper presented at 19th International Conference on International Tourism and Hospitality Management held in Rio de Janeiro, Brazil on February 23-24, 2017.
} 
Regarding the importance of tourism, resources from the World Tourism Organization (UNWTO, 2012) have argued that it provides more economic output than industrial branches such as the automotive, chemical and mining industries. This situation has increased countries' interest in tourism and directed them to act more sensitively in regulating it. For this reason, the importance of tourism has been highlighted both in government programmes and in private sector investment plans in many developed and developing countries. Most countries even provide supporting facilities to encourage tourism investment by entrepreneurs. We can safely say that there is cutthroat competition among countries for tourism revenue. Thus, countries are making efforts to attract tourism investment by removing the legal, economic and bureaucratic barriers facing foreign entrepreneurs or by facilitating arrangements.

It is well known that Turkey has a significant share among other countries with respect to the number of tourists and tourism income. The importance of tourism is recognized in government policies and strategic plans regarding the tourism sector. Turkey's strategic targets include using tourism resources more efficiently and obtaining a larger share of the tourism market, which will therefore improve the economic contribution from the tourism sector. Turkey thus presents significant opportunities for both domestic and foreign entrepreneurs through its alternative tourism attractions and the incentives provided by the government to tourism investors. However, due to the fact that there has been paucity of research in the literature of tourism entrepreneurship and more research studies are needed regarding the local context of Turkey that will reveal the sources of attractions which are potentials for entrepreneurship, it is vitally important to conduct such studies. Based on this, the study was conducted in the city of Afyonkarahisar, Turkey, which has been called "The Capital of Thermal Tourism" with its potentials for future entrepreneurships. The incentives provided by the public authorities have increased the interest of entrepreneurs in the tourism sector. As a result, Afyonkarahisar has attracted the interest of tourism entrepreneurs, and it is rapidly becoming a major destination. The main feature of this study is that it evaluated the tourism sector in Afyonkarahisar based on the perspective of entrepreneurs operating in different lines of business. The use of economic tourism resources in Afyonkarahisar is commonly is more modern when compared with the sectors such as livestock, the marble industry and the confectionary sector. Thus, one might say that entrepreneurs have recently changed their perceptions of the tourism sector and their awareness of the relationship between tourism and many of the other business sectors. Therefore, understanding entrepreneurs' perceptions of the economic, social and physical impacts of the tourism sector will help guide the future of tourism.

\section{Entrepreneurship \& Entrepreneurs}

In the literature, there is not a consensus on the definition of entrepreneurship, but the general tendency towards this concept is that it refers to "the initiation of change through creation or innovation that usually bears risk" (Zhao et. al., 2011, p. 1511). In the area of tourism, entrepreneurship recognized to the extent that it contributes to a society's economy and social welfare. However, an increase in the number of tourism entrepreneurs is not a gift of nature; it is a tourism entrepreneurship event (Koh and Hatten, 2002, pp. 23-24). There are many studies in the tourism literature that examine the entrepreneurship concept. Some of these studies analyse the entrepreneurshiptourism relationship (Dahles and Bras, 1999, p. 268; Weiermair et. al., 2006, p. 23; Lovelock et. al, 2010, p. 270; Bukhari and Hilmi, 2012, p. 133; Matilainen and 
Lähdesmäki, 2014, p. 72,; Kensbock and Jennings, 2014, pp. 490-493) putting forward the conclusion that this relationship promote and develop competition in a positive way in the sector. Some other studies analyse the entrepreneurship environment and its structure (Paniagua, 2002, pp. 362-368; Hallak et. al., 2012, p.145; Power, et al., 2017). Some other studies examine the term of entrepreneurship in a contextual level (Bosworth and Farrell, 2011; Hingtgen et al., 2015) whereas some research the entrepreneurs themselves (Koh and Hatten, 2002, pp. 31-44; Bosworth and Farrell, 2011, pp. 1477-1479).

Entrepreneurs are considered people or groups of people who establish an organization (Katz and Green, 2009). The simplest type of entrepreneur is the selfemployed individual (Blanchflower and Oswald, 1998, p.27). Besides, the term "carries certain connotations regarding the risk-taking, ambitious and possibly innovative or creative characteristics of business owners" (Bosworth and Farrell, 2011, p. 1475) Entrepreneurs are people who obtain benefits from an opportunity that did not previously exist. This opportunity can be an innovative product, a type of new service or an organization itself (Brazeal and Herbert, 1999, p.34). Entrepreneurs are defined in the literature as ambitious, creative, flexible, dynamic, innovative and farsighted people (Arikan, 2004, p.4). For this reason, it is important to analyse and reveal the characteristics of entrepreneurs.

\section{Aim and Methodology of the Study}

The aim of this study is to determine the perceptions of entrepreneurs who are registered with the Chamber of Industry of Trade of Afyonkarahisar (ATSO) and who engage in 25 different lines of business regarding the economic, social and physical impacts of tourism. There are some studies in the literature that examine the impacts of tourism and entrepreneurship (Selby et. al., 2011, pp. 446-447; Hallak et. al., 2012, p. 143; Stylidis et. al., 2015, pp. 260-274). However, studies on the perceptions of entrepreneurs about the economic, social and physical impacts of tourism are limited in number. Therefore, it is expected that this study will make a major contribution to the literature.

To collect the data for this study, we employed a survey that comprised two parts. The first part includes seven questions that aim to determine the demographic characteristics of the respondents (gender, age, marital status, education, inhabitancy, age of business, and relationship with tourism companies). The second part of the survey includes 34 closed-end statements to determine the economic, social and physical impacts of tourism. The statements in the survey were rated on a five-point Likert-type scale. The entrepreneurs were asked to evaluate their opinions on the impacts of tourism between "I do not agree" $=1$ and "I agree completely" $=5$. The second part of the survey was developed by reviewing studies that were previously conducted on this subject (Tsartas, 1992, pp. 516-533; Brunt and Courtney, 1999, p. 499; Carmichael, 2000, pp. 605-606; Davies and Cahill, 2000, pp. 11-33; Çalişkan and Tütüncü, 2008, pp. 812-813; Gümüş and Özüpekçe, 2009, pp. 406-414). Both the content and the comprehensiveness of the survey were checked, and the Cronbach's alpha values shown in Table 3 provide the results of the reliability analysis. To collect the data for the study, a survey method was utilized. The sample comprises the entrepreneurs operating in the city of Afyonkarahisar and registered with the ATSO. The study's population size is 2,670 based on the data obtained from the ATSO. 
Convenience sampling formula suggested for quantitative studies and infinite populations by Lohr (2010, p. 47):

$$
\mathrm{n}_{0}=\frac{S^{2} Z_{\alpha / 2}^{2}}{e^{2}}
$$

In the formula, the symbols represent the elements as follows: $\mathrm{n}_{0}$ : sample size, $\mathrm{Z}_{\alpha / 2}$ : theoretical value for significant level, $\mathrm{S}$ : standart deviation, e: sampling error, $\mathrm{Z}_{\alpha / 2}=1,96$ (for 0,05 ), $\mathrm{S}=1$ and $\mathrm{e}=0,1$. The sample size was calculated as 335 . However, we decided to sample 500 entrepreneurs to increase the reliability of the study and because we expected that there may be invalid surveys.

According to the ATSO's classification, the enterprises operate in 25 different business segments. Based on the stratified sampling method, the number of enterprises in each business segment to be included in the primary sample was calculated according to the percentage share of the total. Then, the names of enterprises were chosen at random using a bag-style bingo. The study was completed over a period of six total months between August 2009 and January 2010. Because some of entrepreneurs terminated their businesses during the period, some could no longer be reached at their previously stated address, and some did not respond to the survey, 480 questionnaires were collected in total. Of these questionnaires, eight were found to be invalid and were not included in the study; thus, we evaluated 472 questionnaires in total. The breakdown of the survey by group is provided in the appendix.

The findings regarding the demographic characteristics of the 472 survey respondents are included in the primary analysis. Then, values for the means and standard deviations of the questions regarding the factors are provided in Table 1. In the third part of the study, the differences between the means of the entrepreneurs' opinions on the economic, social and physical impacts of tourism were compared, and the results are shown in Table 2. In performing the comparisons, the ANOVA test was used in situations where three or more variables were available, and the independent sampling ttest was used for situations where two variables were available. Finally, a confirmatory factor analysis was applied for each factor, and the relationship quantities were determined between the structural equation modelling and the factors. While performing the analysis, the SPSS and LISREL package programs were utilized.

\section{Findings \& Discussion}

The findings for the means and standard deviations of the entrepreneurs' opinions about the social, economic and physical impacts of tourism are shown in Table 1. According to these results, it can be stated that entrepreneurs are conscious about the impacts of tourism. In particular, they view tourism as a social activity, they consider it an area for investment, and they express positive opinions about preserving natural and historical places, thus revealing that entrepreneurs are conscious of tourism-related matters. However, the entrepreneurs also highlighted some negative impacts of tourism with their opinions by stating that tourism helped to destroy the local native language, tourism products and services cause cost increases, and tourism causes the unplanned urbanization and depletion of resources. In fact, although these responses may seem to be negative, we observed that the entrepreneurs determined the situation to be positive overall. Because the assets that create tourism value are composed of elements from man-made and natural sources, the human factor is very important. Thus, it is the 
human factor that both uses the natural resources and creates the attractions. Therefore, entrepreneurs should not forget their responsibilities in producing, consuming and using the tourism resources. The positive results created by tourism should never threaten the principle of sustainability. Therefore, the tourism phenomenon should play a functional role in socialization and should help to raise individuals' awareness instead of being purely economically driven. Positive steps that can be taken in this regard will allow entrepreneurs to contribute to the efficient use of tourism resources, social responsibility and profitability.

Table 1: Perceptions of entrepreneurs regarding the impacts of tourism $(n=472)$

\begin{tabular}{|c|c|c|c|}
\hline 离 & Items & $\overline{\boldsymbol{x}}$ & d.f. \\
\hline \multirow{13}{*}{ 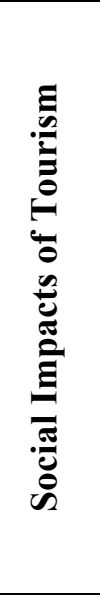 } & It provides opportunities to increase social activities & 4.47 & 0.74 \\
\hline & It develops infrastructure standards & 4.28 & 0.87 \\
\hline & It enhances people's manners & 4.13 & 0.96 \\
\hline & It raises public awareness & 4.24 & 0.86 \\
\hline & It provides opportunities for health & 4.09 & 1.01 \\
\hline & It ensures that the province is safer & 3.67 & 1.10 \\
\hline & It provides increased technological possibilities & 3.75 & 1.05 \\
\hline & It causes the deterioration of traditions & 3.36 & 1.20 \\
\hline & Tourism is likely to increase the crime rate & 3.62 & 1.08 \\
\hline & It adversely affects relationships within the family & 2.61 & 1.16 \\
\hline & Tourism is likely to diminish religious values & 3.38 & 1.24 \\
\hline & Tourism is likely to diminish moral values & 3.37 & 1.26 \\
\hline & Tourism is likely to diminish the Turkish language & 3.44 & 1.28 \\
\hline \multirow{11}{*}{ 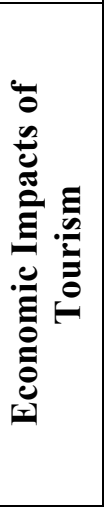 } & It increases the income level of the province & 4.41 & 0.90 \\
\hline & It provides an increase in investment & 4.38 & 0.86 \\
\hline & It increases job opportunities & 4.32 & 0.90 \\
\hline & It provides an increase in state incentives & 4.05 & 1.00 \\
\hline & It increases the potential of the province for tourism & 3.70 & 1.16 \\
\hline & It transfers tourism income to other provinces & 3.06 & 1.15 \\
\hline & It increases the usage of imported goods & 2.84 & 1.04 \\
\hline & It leads to price increases of goods and services & 2.63 & 1.12 \\
\hline & Employment is not dependent on the local people & 2.75 & 1.05 \\
\hline & It causes excessive spending & 3.09 & 1.15 \\
\hline & The benefits created are less than the costs & 2.66 & 1.22 \\
\hline \multirow{10}{*}{ 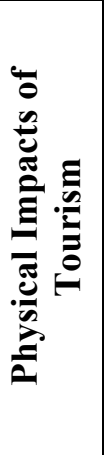 } & It ensures the preservation of tourism resources & 4.24 & 0.97 \\
\hline & It ensures the restoration of historic buildings & 4.22 & 1.05 \\
\hline & Increases in the number of tourists visiting the province are useful & 4.07 & 1.00 \\
\hline & Tourist buildings make the province beautiful & 4.45 & 0.90 \\
\hline & It causes traffic jams & 2.96 & 1.28 \\
\hline & It causes noise pollution & 2.69 & 1.17 \\
\hline & It causes environmental pollution & 2.54 & 1.19 \\
\hline & It causes increases in parking areas & 2.69 & 1.27 \\
\hline & It causes concretization & 2.54 & 1.30 \\
\hline & It causes reductions in tourism resources & 2.86 & 1.28 \\
\hline
\end{tabular}

Table 2 includes the t-test and ANOVA results for the comparison of the means of the opinions of the respondents on the economic, social and physical impacts of tourism 
based on the demographic characteristics. According to these results, the opinions of the entrepreneurs on the economic, social and physical impacts of tourism do not demonstrate statistically significant differences based on the duration of their relationships with their tourist enterprises $(p>0.05)$. However, the opinions of the entrepreneurs on the economic impacts of tourism do show differences based on the gender factor. The results show that male entrepreneurs pay more attention to the economic aspects of tourism than the female entrepreneurs. In addition, the social impacts of tourism are significant based on marital status $(p<0.05)$. Thus, married entrepreneurs express a more sensitive attitude towards the social impacts of tourism. Another statistically significant difference was found in the educational background of entrepreneurs regarding their opinions about the economic and social impacts of tourism $(\mathrm{p}<0.05)$. Specifically, entrepreneurs with a high level of education demonstrate a positive sensitivity regarding the impacts of tourism. Hence, we can say that the education factor is the most significant capital for entrepreneurs. Additionally, there is a statistically significant difference between the business experiences of the entrepreneurs and their opinions about the social impacts of tourism $(\mathrm{p}<0.05)$. We can state that young entrepreneurs with business experience are more sensitive to the social impacts of tourism.

Table 2: Comparison of Means regarding the Social, Economic and Physical Impacts of Tourism with the Demographic Characteristics of Entrepreneurs

\begin{tabular}{|c|c|c|c|c|c|c|}
\hline Variables & Factor & Group & n & $\bar{x}$ & d.f. & (p) \\
\hline \multirow{6}{*}{ 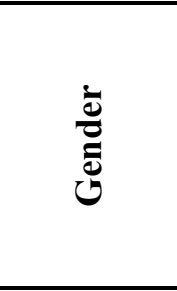 } & \multirow{2}{*}{ Social } & Female & 61 & 3.80 & 0.52 & \multirow{2}{*}{0.138} \\
\hline & & Male & 411 & 3.71 & 0.43 & \\
\hline & \multirow{2}{*}{ Economic } & Female & 61 & 3.32 & 0.54 & \multirow{2}{*}{$* 0.028$} \\
\hline & & Male & 411 & 3.46 & 0.46 & \\
\hline & \multirow{2}{*}{ Physical } & Female & 61 & 3.24 & 0.58 & \multirow{2}{*}{0.237} \\
\hline & & Male & 411 & 3.34 & 0.59 & \\
\hline \multirow{12}{*}{$\underset{4}{\mathscr{\infty}}$} & \multirow{4}{*}{ Social } & $18-24$ & 38 & 3.72 & 0.29 & \multirow{4}{*}{0.539} \\
\hline & & $25-34$ & 113 & 3.77 & 0.45 & \\
\hline & & $35-44$ & 151 & 3.73 & 0.44 & \\
\hline & & $45+$ & 170 & 3.69 & 0.47 & \\
\hline & \multirow{4}{*}{ Economic } & $18-24$ & 38 & 3.45 & 0.51 & \multirow{4}{*}{0.460} \\
\hline & & $25-34$ & 113 & 3.50 & 0.46 & \\
\hline & & $35-44$ & 151 & 3.44 & 0.47 & \\
\hline & & $45+$ & 170 & 3.41 & 0.48 & \\
\hline & \multirow{4}{*}{ Physical } & $18-24$ & 38 & 3.33 & 0.56 & \multirow{4}{*}{0.076} \\
\hline & & $25-34$ & 113 & 3.40 & 0.59 & \\
\hline & & $35-44$ & 151 & 3.37 & 0.59 & \\
\hline & & $45+$ & 170 & 3.23 & 0.58 & \\
\hline \multirow{6}{*}{ 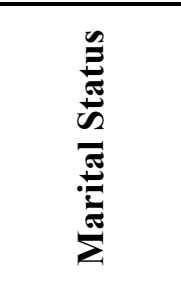 } & \multirow{2}{*}{ Social } & Married & 103 & 3.81 & 0.43 & \multirow{2}{*}{$* 0.029$} \\
\hline & & Single & 369 & 3.70 & 0.45 & \\
\hline & \multirow{2}{*}{ Economic } & Married & 103 & 3.50 & 0.41 & \multirow{2}{*}{0.217} \\
\hline & & Single & 369 & 3.43 & 0.49 & \\
\hline & \multirow{2}{*}{ Physical } & Married & 103 & 3.35 & 0.56 & \multirow{2}{*}{0.697} \\
\hline & & Single & 369 & 3.32 & 0.60 & \\
\hline
\end{tabular}


Table 2 (Continuation): Comparison of Means regarding the Social, Economic and Physical Impacts of Tourism with the Demographic Characteristics of Entrepreneurs

\begin{tabular}{|c|c|c|c|c|c|c|}
\hline \multirow{18}{*}{ 氖 } & \multirow{6}{*}{ Social } & Primary & 37 & 3.65 & 0.45 & \multirow{6}{*}{$* 0.048$} \\
\hline & & Secondary & 77 & 3.67 & 0.50 & \\
\hline & & High School & 183 & 3.67 & 0.44 & \\
\hline & & Associate's degree & 55 & 3.80 & 0.40 & \\
\hline & & Bachelor's degree & 113 & 3.82 & 0.39 & \\
\hline & & Postgraduate & 7 & 3.74 & 0.56 & \\
\hline & \multirow{6}{*}{ Economic } & Primary & 37 & 3.34 & 0.44 & \multirow{6}{*}{$* 0.031$} \\
\hline & & Secondary & 77 & 3.39 & 0.49 & \\
\hline & & High School & 183 & 3.41 & 0.51 & \\
\hline & & Associate's degree & 55 & 3.47 & 0.45 & \\
\hline & & Bachelor's degree & 113 & 3.57 & 0.40 & \\
\hline & & Postgraduate & 7 & 3.36 & 0.55 & \\
\hline & \multirow{6}{*}{ Physical } & Primary & 37 & 3.32 & 0.56 & \multirow{6}{*}{0.136} \\
\hline & & Secondary & 77 & 3.17 & 0.68 & \\
\hline & & High School & 183 & 3.32 & 0.59 & \\
\hline & & Associate's degree & 55 & 3.38 & 0.57 & \\
\hline & & Bachelor's degree & 113 & 3.42 & 0.52 & \\
\hline & & Postgraduate & 7 & 3.31 & 0.54 & \\
\hline \multirow{9}{*}{ 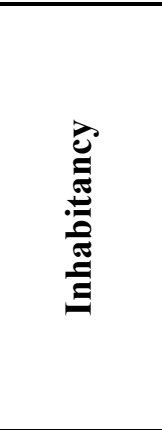 } & \multirow{3}{*}{ Social } & $1-9$ & 84 & 3.80 & 0.37 & \multirow{3}{*}{0.072} \\
\hline & & $10-19$ & 33 & 3.59 & 0.42 & \\
\hline & & $20+$ & 355 & 3.72 & 0.46 & \\
\hline & \multirow{3}{*}{ Economic } & $1-9$ & 84 & 3.44 & 0.47 & \multirow{3}{*}{0.215} \\
\hline & & $10-19$ & 33 & 3.31 & 0.60 & \\
\hline & & $20+$ & 355 & 3.46 & 0.46 & \\
\hline & \multirow{3}{*}{ Physical } & $1-9$ & 84 & 3.38 & 0.66 & \multirow{3}{*}{0.590} \\
\hline & & $10-19$ & 33 & 3.29 & 0.67 & \\
\hline & & $20+$ & 355 & 3.32 & 0.56 & \\
\hline \multirow{12}{*}{ 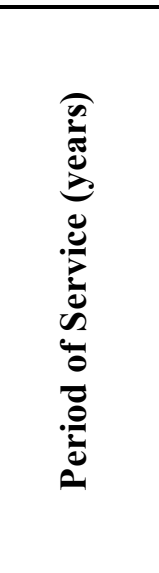 } & \multirow{4}{*}{ Social } & $1-9$ & 122 & 3.78 & 0.39 & \multirow{4}{*}{$* 0.021$} \\
\hline & & $10-19$ & 190 & 3.74 & 0.46 & \\
\hline & & $20-29$ & 127 & 3.69 & 0.40 & \\
\hline & & $30+$ & 33 & 3.52 & 0.64 & \\
\hline & \multirow{4}{*}{ Economic } & $1-9$ & 122 & 3.43 & 0.39 & \multirow{4}{*}{0.475} \\
\hline & & $10-19$ & 190 & 3.49 & 0.48 & \\
\hline & & $20-29$ & 127 & 3.41 & 0.51 & \\
\hline & & $30+$ & 33 & 3.41 & 0.57 & \\
\hline & \multirow{4}{*}{ Physical } & $1-9$ & 122 & 3.38 & 0.58 & \multirow{4}{*}{0.561} \\
\hline & & $10-19$ & 190 & 3.33 & 0.59 & \\
\hline & & $20-29$ & 127 & 3.28 & 0.58 & \\
\hline & & $30+$ & 33 & 3.26 & 0.61 & \\
\hline \multirow{6}{*}{ 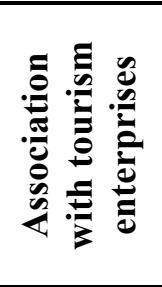 } & \multirow{2}{*}{ Social } & Yes & 215 & 3.70 & 0.46 & 0301 \\
\hline & & No & 257 & 3.74 & 0.43 & 0.301 \\
\hline & Economic & Yes & 215 & 3.48 & 0.48 & \\
\hline & Economic & No & 257 & 3.41 & 0.47 & 0.102 \\
\hline & & Yes & 215 & 3.37 & 0.58 & \\
\hline & Physical & No & 257 & 3.29 & 0.59 & 0.172 \\
\hline
\end{tabular}


To determine the degrees of causal consequences of the opinions of entrepreneurs regarding the social, economic and physical impacts of tourism, structural equation modelling was utilized. As a result of these analyses, factor analysis was applied to the data to ensure the validity of the structural equation modelling approach. The calculation of the KMO value as 0.805 shows that factor analysis can be applied to the data. The ratio of total variant explanation was determined to be approximately $65 \%$. The result of the SEM analysis is presented in Table 3 and the output indices taking place in this table are identified in the light of Alcántara-Pilar \& Barrio-García's, (2015, p. 392) research.

Table 3: Results of the Explanatory Factor Analysis

\begin{tabular}{|c|c|c|c|c|c|c|c|}
\hline Factors & & $\begin{array}{l}\text { Factor } \\
\text { Loadings }\end{array}$ & $\begin{array}{l}\text { Eigen } \\
\text { value }\end{array}$ & AVE & $\mathbf{C R}$ & $\begin{array}{l}\text { \% variance } \\
\text { explained }\end{array}$ & $\alpha$ \\
\hline $\mathbf{P P}$ & $\begin{array}{l}\text { Physical Impacts of Tourism } \\
\text { (Positive) }\end{array}$ & & 1.326 & 0.64 & 0.78 & 7.042 & 0.780 \\
\hline PP25 & $\begin{array}{l}\text { Ensures the preservation of } \\
\text { tourism resources }\end{array}$ & 0.837 & & & & & \\
\hline PP26 & $\begin{array}{l}\text { Ensures the restoration of historic } \\
\text { buildings }\end{array}$ & 0.858 & & & & & \\
\hline $\mathbf{P N}$ & $\begin{array}{l}\text { Physical Impacts of Tourism } \\
\text { (Negative) }\end{array}$ & & 4.034 & 0.47 & 0.83 & 12.785 & 0.839 \\
\hline PN29 & Causes heavy traffic & 0.731 & & & & & \\
\hline PN30 & Causes air pollution & 0.673 & & & & & \\
\hline PN31 & Causes environmental pollution & 0.673 & & & & & \\
\hline PN32 & Causes overcrowding in parks & 0.569 & & & & & \\
\hline PN33 & Causes concretization & 0.621 & & & & & \\
\hline FN34 & Causes the depletion of resources & 0.751 & & & & & \\
\hline $\mathbf{S P}$ & $\begin{array}{l}\text { Social Impacts of Tourism } \\
\text { (Positive) }\end{array}$ & & 2.064 & 0.48 & 0.81 & 12.149 & 0.807 \\
\hline SP1 & $\begin{array}{l}\text { Causes increases in social activity } \\
\text { opportunities }\end{array}$ & 0.650 & & & & & \\
\hline SP2 & Develops infrastructure standards & 0.796 & & & & & \\
\hline SP3 & Enhances people’s manners & 0.802 & & & & & \\
\hline SP4 & Raises public awareness & 0.819 & & & & & \\
\hline SP5 & Develops opportunities for health & 0.583 & & & & & \\
\hline $\mathbf{S N}$ & $\begin{array}{l}\text { Social Impacts of Tourism } \\
\text { (Negative) }\end{array}$ & & 5.916 & 0.60 & 0.71 & 14.727 & 0.433 \\
\hline SN9 & Increases the crime rate & 0.611 & & & & & \\
\hline SN10 & $\begin{array}{l}\text { Adversely affects relationships } \\
\text { within the family }\end{array}$ & 0.738 & & & & & \\
\hline SN11 & Destroys religious values & 0.886 & & & & & \\
\hline SN12 & Destroys moral values & 0.849 & & & & & \\
\hline SN13 & $\begin{array}{l}\text { Leads to erosion of the Turkish } \\
\text { language }\end{array}$ & 0.766 & & & & & \\
\hline EP & $\begin{array}{l}\text { Economic Impacts of Tourism } \\
\text { (Positive) }\end{array}$ & & 1.596 & 0.56 & 0.83 & 11.150 & 0.839 \\
\hline EP14 & $\begin{array}{l}\text { Increases the income level of the } \\
\text { province }\end{array}$ & $\mathbf{0 . 8 3 7}$ & & & & & \\
\hline EP15 & Leads to increases in investment & 0.885 & & & & & \\
\hline EP16 & Increases job opportunities & 0.839 & & & & & \\
\hline EP17 & $\begin{array}{l}\text { Leads to increases in state } \\
\text { incentives }\end{array}$ & 0.632 & & & & & \\
\hline $\mathbf{E N}$ & $\begin{array}{l}\text { Economic Impacts of Tourism } \\
\text { (Negative) }\end{array}$ & & 1.135 & 0.34 & 0.60 & 6.435 & 0.601 \\
\hline EN19 & $\begin{array}{l}\text { Employment is not dependent on } \\
\text { the local people }\end{array}$ & 0.857 & & & & & \\
\hline EN20 & $\begin{array}{l}\text { Causes the transfer of local } \\
\text { tourism income to other cities }\end{array}$ & 0.609 & & & & & \\
\hline EN22 & $\begin{array}{l}\text { Increases the use of imported } \\
\text { goods }\end{array}$ & 0.514 & & & & & \\
\hline
\end{tabular}


The results of the structural equation model examining the perceptions of entrepreneurs regarding the impacts of tourism can be observed in Figure 1. The results show that the developed structural equation model was congruent with the empirical data. The value of $\mathrm{X}^{2} / \mathrm{sd}$., which is used to evaluate the model's compliance, is less than

3 , which demonstrates that the model's compliance is acceptable (Yilmaz et. al., 2011:272).

Table 4: Compliance Indices

\begin{tabular}{|c|c|c|c|}
\hline $\begin{array}{c}\text { Measurement } \\
\text { Index }\end{array}$ & $\begin{array}{c}\text { Goodness-of-fit } \\
\text { statistic }\end{array}$ & Acceptable & Model \\
\hline RMSEA & $0<$ RMSEA $<0.05$ & $0.05 \leq$ RMSEA $\leq 0.10$ & 0.065 \\
\hline NFI & $0.95 \leq \mathrm{NFI} \leq 1$ & $0.90 \leq \mathrm{NFI} \leq 0.95$ & 0.920 \\
\hline NNFI & $0.97 \leq \mathrm{NNFI} \leq 1$ & $0.95 \leq \mathrm{NFI} \leq 0.97$ & 0.940 \\
\hline CFI & $0.97 \leq \mathrm{CFI} \leq 1$ & $0.95 \leq \mathrm{CFI} \leq 0.97$ & 0.950 \\
\hline GFI & $0.95 \leq \mathrm{GFI} \leq 1$ & $0.90 \leq \mathrm{GFI} \leq 0.95$ & 0.900 \\
\hline AGFI & $0.90 \leq \mathrm{AGFI} \leq 1$ & $0.85 \leq \mathrm{AGFI} \leq 0.90$ & 0.850 \\
\hline
\end{tabular}

(Source: Schermelleh-Engel and Moosbrugger, 2003: 36).

The package software used in the Structural Equation Model (SEM) analysis shows different results for the compliance indices. LISREL users usually interpret the results based on the compliance indices such as GFI, AGFI, RMSEA, CFI and NNFI in addition to the Chi-Square value (Sümer, 2000, pp. 61-62). As a result of the analysis, Table 4 indicates that the model's compliance indices show good compliance. In addition, corrections were made in line with the modifications suggested by the software. SEM Figure 1 shows entrepreneurs' perceptions of the economic, social and physical impacts of tourism.

In line with this information, the variable with the highest positive effect regarding the social impacts of tourism was "SP3: It enhances people's manners", with a ratio of 0.85 . Thus, a one-unit increase in the SP3 variable will lead to an increase of 0.85 on the SP (social positive). The next largest effect is "SP4: It raises the awareness of the public", with an effect of 0.79 . The least effective variable on SP is "SP1: It provides opportunities to increase social activities", with a ratio of 0.49 . The results show that the entrepreneurs believe that tourism is a social activity that creates positive contributions to the public. Thus, the entrepreneurs did not demonstrate a conservative attitude about tourism events. They explained the role of tourism as improving the public's quality of life. This result shows that entrepreneurs have positive beliefs about tourism investments when they are asked about their awareness of the impacts of tourism. 


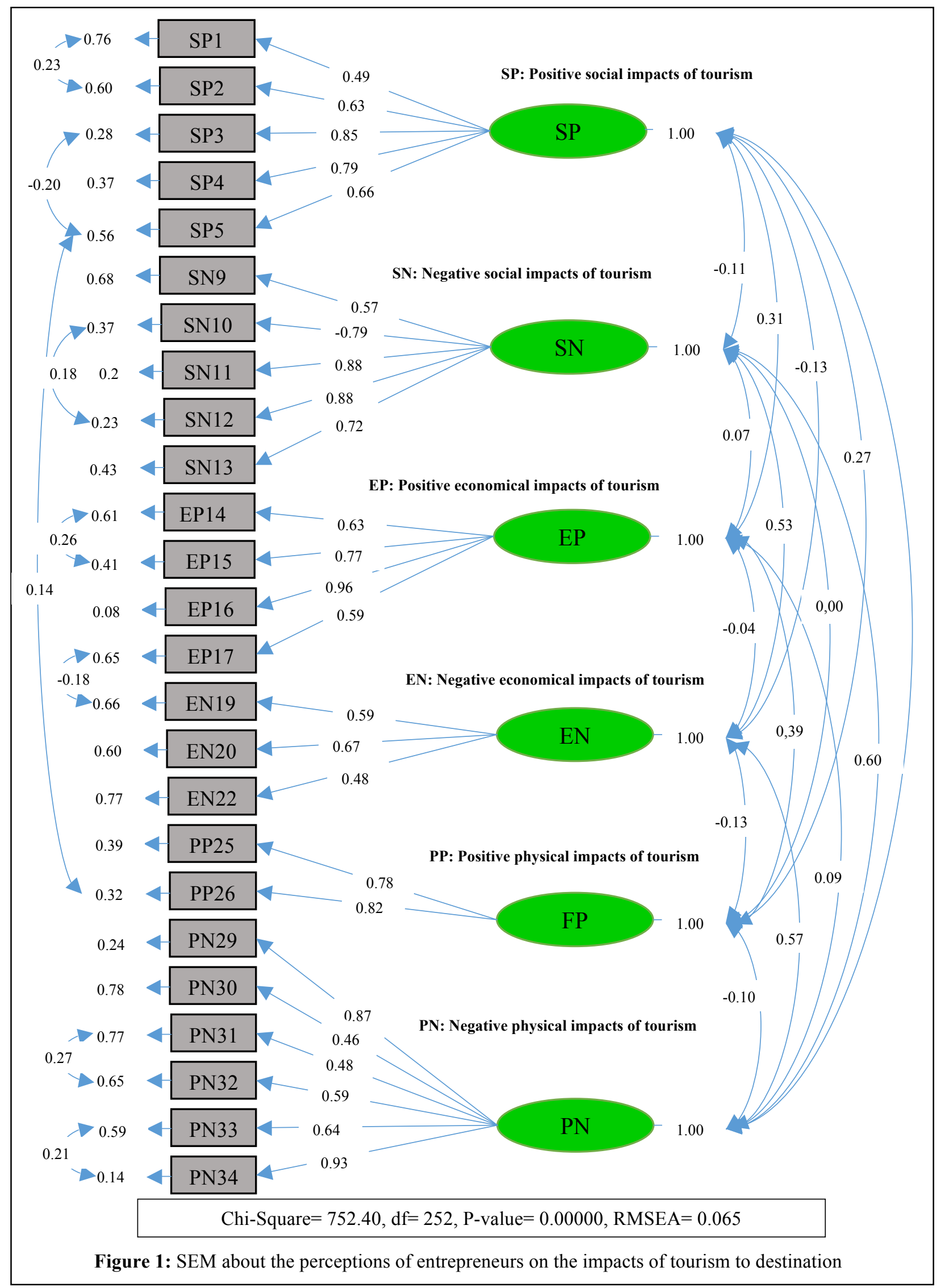


The variables with greatest effects on the negative social impacts include "SN11: It leads to a reduction in religious values", with a value of 0.88 , and "SN12: It leads to a reduction in moral values". Thus, a one-unit change in the SP11 and SP12 variables will lead to a difference of 0.88 on the SN (social negative). The variable "SN10: It adversely affects relationships within the family" has a negative effect of -0.79 on the SN. The factor "SN9: It increases the crime rate" is the least effective variable, with a value of 0.57 on the SN. The results show that the entrepreneurs demonstrate a sensitive attitude regarding the attitudes about faith in their society. Therefore, it can be stated that tourism's requirement of openness to interaction with different cultures can affect the investment decisions of entrepreneurs. Hence, it is necessary to raise the community's awareness to reduce the socially negative impacts of tourism and entrepreneurs' concerns. In addition, we can state that the public factors can affect entrepreneurs' choice of investment area and their decision-making process.

The variable with the greatest effect on the positive economic impacts was "EP16: It provides increased job opportunities". A one-unit change in EP16 leads to a difference of 0.96 on the EP (economic positive). The least effective variable on the EP was "EP17: It provides increased state incentives", with a ratio of 0.59 . One of the significant features of tourism is its positive impacts on employment. Naturally, the proliferation of tourism investments will also increase employment opportunities. However, the entrepreneurs did not believe that tourism increases public incentives. Incentives provided by the public to the tourism sector lower the investment costs for entrepreneurs and make such investments more attractive. Therefore, knowing the expectations of entrepreneurs can benefit all parties.

The variable with the greatest effect on the negative economic impacts was "EN20: It increases the use of imported goods". A one-unit change in EN20 leads to a difference of 0.67 on the EN (economic negative). This variable is followed by "EN19: It transfers tourism income to other provinces", with a ratio of 0.59 . The least effective variable is "EN22: "Employment is not dependent on the local people", with a ratio of 0.48. These results indicate that entrepreneurs know how the tourism sector functions. Specifically, imports of goods and services required for industrial production lead to currency leaving the country. Thus, the tourism sector, in addressing international markets, needs to use imported goods to fulfil the expectations of the tourism sector and ensure quality standards. Although this situation seems to be a negative factor, in fact, it creates a positive cycle by the benefits that it provides.

The variable with the greatest effect on the positive physical (PP) impacts was "PP26: It ensures the restoration of historic buildings". A one-unit change in PP26 leads to a difference of 0.82 in the PP. The ratio for the other variable (PP25) is as 0.78 . Thus, a one-unit change in "PP25: It ensures the preservation of tourism resources" will lead to an increase of 0.78 on the PP. One of the basic products of tourism is historical assets. The past life of communities and the traces left behind drive people to travel. Therefore, the preservation and celebration of historic assets can only be ensured by the awareness of the importance of tourism. A region's wealth of tourist attractions will garner the attention of both visitors and entrepreneurs.

The variable with the greatest effect on the negative physical impacts is "PN34: It causes a reduction in tourism resources", with a ratio of 0.93 . This variable is followed by "PN29: Causes heavy traffic", with a ratio of 0.87 . The variable with lowest effect 
on the PN (physical negative) is "PN30: It causes noise pollution". A one-unit change in PN30 leads to a difference of 0.46 on the PN (physical negative). Although tourism is an activity that can take place during all twelve months of the year, some periods have excessive overcrowding. At times of overcrowding, tourism resources are depleted excessively and can even be under the threat of extinction. The entrepreneurs indicated that they were aware of this situation based on their opinions. From this perspective, plans that will not threaten the needs and quality of life of the next generations will be beneficial to creating sustainable tourism. Both the satisfaction of tourists and the profitability of their investments are important issues for entrepreneurs. Therefore, the expectations of tourism stakeholders should never supersede the interests of society.

\section{Conclusion}

Based on the results of this study, entrepreneurs have perceptions regarding both the positive and negative impacts of tourism. These impacts were grouped in the study as social, economic and physical impacts. Another result is that the opinions of the entrepreneurs regarding the social, economic and physical impacts of tourism do not demonstrate statistically significant differences based on some demographic characteristics (age, time of stay and relationship with tourist enterprises). However, the results show that male entrepreneurs pay more attention to the economic aspects of tourism than female entrepreneurs. This difference could be explained by the fact that female entrepreneurs have less experience in economic life than the male entrepreneurs. Conversely, married entrepreneurs indicated a more sensitive attitude towards the social impacts of tourism. Because tourism requires continuous, 24/7 service and is an extremely labour-intensive sector, it limits people's social life. Therefore, married entrepreneurs who know how the tourism sector functions indicated that they are more sensitive than single entrepreneurs on this issue. In addition, entrepreneurs with a high educational background expressed more positive opinions than entrepreneurs with lower educational levels on the social, economic and physical impacts of tourism. Thus, as the entrepreneurs' level of education increases, their opinions on the impacts of tourism change in a positive direction. Another significant difference was observed between the entrepreneurs' business experience and the social impacts of tourism. Entrepreneurs with business experience of 1 to 9 years are more sensitive than those with more business experience regarding the social impacts of tourism. This result shows that young entrepreneurs are outward-oriented and have a high level of social awareness.

The study was conducted in a region, Afyonkarahisar, which is mainly formed by thermal managements as a tourist destination. Due to the lack of research focusing on tourism entrepreneurships in thermal destinations, it is not possible to discuss the findings of the current study with the ones in the literature and the generalizing the findings of in it such a discussion would have created a limitation for this study.

Based on the results of the SEM analysis, the social-positive, social-negative, economic-positive, economic-negative, physical-positive and physical-negative impacts of tourism have relationships with each other, and the degrees and directions of interaction are shown in Figure 1. The results of this study show that although tourism is important for the economy of Afyonkarahisar, the entrepreneurs revealed that it has both positive and negative impacts on the social, economic and physical life of the province. This study also reveals a relationship between the social, economic and physical impacts of tourism. Thus, this aspect of the study can be a guiding feature for 
tourism stakeholders. It also offers opportunities to entrepreneurs and other stakeholders to solve the problems related to tourism. Moreover, it provides more specific messages to the parties for reducing the negative impacts of tourism on the entire province and for improving the positive impacts. However, it should be noted that as a limitation of this study is towards tourism sector only and more specifically the city of Afyonkarahisar. In order to generalize the findings of the study, it is essential that more comprehensive research covering more aspects of tourism business should be conducted with newer data. Besides, considering the multi-structural nature of tourism business, periodical research with stakeholders is of great significance for future studies.

\section{References}

Alcántara-Pilar, J. M., and Barrio-García, S. D. (2015). Antecedents of Attitudes toward the Website', Cross Cultural Management, 22(3), pp.379-404. Doi:10.1108/CCM-04-2014-0044.

Arikan, S. (2004). Girişimcilik Temel Kavramlar ve Bazı Güncel Konular, Ankara, Turkey: Siyasal Kitabevi

Blanchflower, D.G. \& Oswald, A.J. (1998). What Makes an Entrepreneur?, Journal of Labor Economics, 16(1), pp.26-60.

Bosworth, G. \& Farrell, H. (2011). Tourism entrepreneurs in Northumberland, Annals of Tourism Research, Vol. 38, No. 4, pp. 1474-1494.

Bosworth, G. and Farrell, H. (2011). Tourism Entrepreneurs in Northumberland', Annals of Tourism Research, 38(4), pp.1474-1494.

Brazeal, D.V. and Herbert, T.T. (1999). The Genesis of Entrepreneurship, Entrepreneurship Theory and Practice, 23(3), pp. 29-45.

Brunt, P. \& Courtney, P. (1999). Host Perceptions of Sociocultural Impacts', Annals of Tourism Research, 26(3), pp. 493-515.

Bukhari, A.M.M. \& Hilmi, M.F. (2012). Challenges and Outcome of Innovative Behavior: A Qualitative Study of Tourism Related Entrepreneurs', Journal of Technology Management \& Innovation, 7(2), pp. 131-142.

Çalışkan, U. \& Tütüncü, Ö. (2008). Turizmin Yerel Halk Üzerindeki Etkileri ve Kuşadası İlçesi Uygulaması, IV. Lisansüstü Turizm Öğrencileri Araştırma Kongresi: 23-27 Nisan 2008. Belek, Antalya, Turkey, pp. 806-824.

Carmichael, B. A. (2000). A Matrix Model for Resident Attitudes and Behaviours in a Rapidly Changing Tourist Area, Tourism Management, 21(6), pp. 601-611.

Dahles, H. \& Bras, K. (1999). Entrepreneurs in Romance Tourism in Indonesia, Annals of Tourism Research, 26(2), pp. 267-293.

Davies, T. \& Cahill, S. (2000). Environmental Implications of the Tourism Industry. Discussion Paper, pp.1-40,https://www.csu.edu/cerc/documents/ Environmental Implications Tourism Industry 2000.pdf (Access Date: 08.03.2017, 19:30).

Glavas, C., Pike, S. \& Mathews, S. (2014). Internet-enabled Tourism Entrepreneurs. International Entrepreneurial Values Elicited through Repertory Test and Laddering Analysis, International Journal of Tourism Research, 16, pp. 44-55.

Gümüş, N. \& Özüpekçe, S. (2009). The opinions of Residents Towards Economic, Social, Cultural and Environmental Impacts of Tourism in Foça, Journal of Human Sciences, Vol 6, No 2, pp. 398-417. 
Hallak, R., Brown, G. \& Lindsay, J. N. (2012). The Place Identity-Performance Relationship among Tourism Entrepreneurs: A Structural Equation Modelling Analysis, Tourism Management, 33(1), pp. 143-154.

Hingtgen, N.; Kline, C., Fernandes, L., \& McGehee, N. G. (2015). Cuba in Transition: Tourism Industry Perceptions of Entrepreneurial Change, Tourism Management, (50), pp. 184-193.

Katz, J. A. \& Green, R. P. (2009). Entrepreneurial Small Businesses. Irwin, NY: McGraw-Hill.

Kensbock, S. \& Jennings, G. (2011). Pursuing: A Grounded Theory of Tourism Entrepreneurs' Understanding and Praxis of Sustainable Tourism, Asia Pacific Journal of Tourism Research, 16(5), pp. 489-504.

Koh, K.Y\& Hatten, T.S. (2002). The Tourism Entrepreneur: The Overlooked Player in Tourism Development Studies, International Journal of Hospitality \& Tourism Administration, 3(1), pp. 21-48.

Lohr, L. S. (2010). Sampling: Design and Analysis. Sec. Edition. Boston:rooks/Cole.

Lovelock, B., Lovelock, K. \& Normann, Ø. (2010). The Big Catch: Negotiating the Transition from Commercial Fisher to Tourism Entrepreneur in Island Environments, Asia Pacific Journal of Tourism Research, 15(3), pp. 267-283.

Matilainen, A. \& Lähdesmäki, M. (2014). Nature-based Tourism in Private Forests: Stakeholder Management Balancing the Interests of Entrepreneurs and Forest Owners?, Journal of Rural Studies, 34, pp. 70-79.

Nunkoo, R., (2015). Tourism Development and Trust in Local Government, Tourism Management (46), pp. 623-634.

Paniagua, A. (2002). Urban-rural Migration, Tourism Entrepreneurs and Rural Restructuring in Spain, Tourism Geographies. An International Journal of Tourism Space, Place and Environment, 4(4), pp. 349-371.

Power, S., Di Domenico, M. \& Miller, G. (2017). The Nature of Ethical Entrepreneurship in Tourism, Annals of Tourism Research (65), pp. 36-48.

Schermelleh-Engel, K. \& Moosbrugger, H. (2003). Evaluating the Fit of Structural Equation Models: Tests of Significance and Descriptive Goodness-Of-Fit Measures, Methods of Psychological Research, 8(2), pp. 23-74.

Seetanah, B. (2011). Assessing the Dynamic Economic Impact of Tourism for Island Economies, Annals of Tourism Research, Vol. 38, No. 1, pp. 291-308.

Selby, A., Petäjistö, L. \& Huhtala, M. (2011). The Realisation of Tourism Business Opportunities Adjacent to Three National Parks In Southern Finland: Entrepreneurs and Local Decision-Makers Matter, Forest Policy and Economics, Volume 13 (6), pp. 446-455.

Stylidis, D., Biran, A., Sit, J. \& Szivas, E. M. (2015). Residents' Support for Tourism Development: The Role of Residents, Tourism Management, (45), pp. 260-274.

Sümer, N. (2000). Yapısal Eşitlik Modelleri: Temel Kavramlar ve Örnek Uygulama, Türk Psikoloji Yazıları, 3(6), pp. 49-73.

Tsartas, P. (1992). Socioeconomic Impacts of Tourism on Two Greek Isles, Annals of Tourism Research, 19(3), 516-533. http://dx.doi.org/10.1016/01607383(92)90134-B

UNWTO. (2012). United Nations Environment Programme and World Tourism Organization, Tourism in the Green Economy-Background Report, 2012, Madrid. (Access Date: 08.03.2017, 20:34 PM). 
Weiermair, K., Siller, J. H. \& Mössenlechner, C. (2006). Entrepreneurs and Entrepreneurship in Alpine Tourism, Journal of Teaching in Travel \& Tourism, 6(2), pp. 23-40.

Yılmaz, V., Yıldız, Z. \& Arslan, T. (2011). Üniversite Öğrencilerinin Çevresel Duyarlılıkları ile Çevresel Davranışlarının Yapısal Eşitlik Modeliyle Araştırılması, Dumlupınar Üniversitesi Sosyal Bilimler Dergisi, 30, pp. 271-278.

Zhao, W., J.R. Brent Ritchie, J. R. \& Echtner, C. M. (2011). Social Capital and Tourism Entrepreneurship, Annals of Tourism Research, Vol. 38, No. 4, pp. 1570-1593. 